\title{
前立腺癌細胞における転写因子 $\mathrm{NF} \varkappa \mathrm{B}$ の活性化と
}

\section{細胞接着分子の発現制御}

\author{
名古屋市立大学医学部泌尿器科学教室（主任：郡健二郎教授）
}

戸 澤 啓 一

\section{ACTIVATION OF NUCLERA FACTOR- $\varkappa$ B AND CONTROL OF THE EXPRESSION OF CELL ADHESION MOLECULES IN HUMAN PROSTATE CANCER CELLS}

\author{
Keiichi Tozawa \\ Department of Urology, Nagoya City University School of Medicine \\ (Chief: Prof. K. Kohri)
}

(Purpose) Cell adhesion molecules (CAMs) have been considered to play key roles in cancer metastasis through binding of cancer cells to the endothelial cells or matrix. We have found that constitutive expression of E-selectin, ICAM-1 (intercellular adhesion molecule-1) and VCAM-1 (vascular cell adhesion molecule-1) on the cell surface of prostate cancer cell lines, PC-3 LNCaP, and DU145. In an attempt to explain the highly metastatic potential of these cells, we investigated expression of CAMs. Since these expressed CAMs are known to be regulated by a transcription factor $\mathrm{NF} \varkappa \mathrm{B}$. We have examined if $\mathrm{NF} \varkappa \mathrm{B}$ is activated in these prostate cancer cell lines.

(Material and Method) Expression of E-selectin, ICAM-1, Sialyl-Lewis X, LFA-1 (lymphocyte function-associated antigen-1), integrin $\alpha 4$, and integrin $\beta 1$ were examined by indirect immunofluorescent staining and Western blotting using specific monoclonal antibodies. We then examined whether pro-inflammatory cytokines known to stimulate $\mathrm{NF} \varkappa \mathrm{B}$, IL- 1 and TNF, could drive the nuclear translocation of $\mathrm{NF} \varkappa \mathrm{B}$. Ten $\mathrm{ng} / \mathrm{ml}$ of recombinant human IL- $1 \beta$ or TNF $\alpha$ was added to the cell culture and the CAMs level, as well as nuclear translocation of $\mathrm{NF} \varkappa \mathrm{B}$, was examined.

(Results) The staining levels of ICAM-1, VCAM-1, and integrin $\beta 1$ were highly elevated in PC-3 and DU145. In surprising, $\mathrm{NF} \varkappa \mathrm{B}$ was retained in the cytoplasm (as an inactive form) and not detectable in the nucleus (active form) as demonstrated by immunofluorescence. Although time-dependent expression of these molecules were explored, the level of ICAM-1 and VCAM-1 on the cell surface were unchanged. However, nuclear translocation of $\mathrm{NF} \varkappa \mathrm{B}$ could be induced.

(Conclusion) These observations indicate that while the signaling pathway to $\mathrm{NF} \varkappa \mathrm{B}$ is intact, it is not directed to induction of its target CAM genes. It is possible that other transcription factors might be involved in these cells and that they might to be constitutively stimulated during the carcinogenesis of prostate cancer.

Key words: cell adhesion molecule, $\mathrm{NF} \varkappa \mathrm{B}$, prostate cancer

要旨：(目的)細胞接着分子は癌細胞と血管内皮細胞および細胞外基質との接着という過程を通して癌の 転移において非常に重要な役割を演じている．前立腺癌細胞株 LNCaP，PC-3，およびDU145の高転移 能と血管内皮細胞上に発現している細胞接着分子との関連を明らかにするため本研究を行った．さらに これら細胞接着分子遺伝子の発現制御を行っていると考えられる転写因子 $\mathrm{NF} \varkappa \mathrm{B}$ の発現, 活性化につい ても検討した。

(方法) 前立腺癌細胞株を用いて, E-selectin, ICAM-1, VCAM-1, Sialyl-LewisX, LFA-1, integrin $\alpha 4$, $\beta 1$ の各細胞接着分子に対するモノクローナル抗体および $\mathrm{NF} \boldsymbol{\kappa} \mathrm{B}$ に対するポリクローナル抗体による免 
疫蛍光染色，フローサイトメトリー，Western blotting を行った。また血管内皮細胞を用い前立腺癌細 胞 3 株との単層細胞接着アッセイおよび各細胞接着分子に対するモノクローナル抗体による細胞接着阻 害実験を行った。

(結果, 結論) 前立腺癌細胞株において E-selectin, ICAM-1, VCAM-1の発現が認められ, 特に ICAM1が血管内皮細胞との接着に重要な役割を果たしていると考えられた。また，この発現は $\mathrm{NF} \varkappa \mathrm{B}$ 以外の 転写因子により制御されており，これら細胞接着分子の構成的発現が高い転移能に結びついていること が示唆された。

キーワード：細胞接着分子，転写因子 $\mathrm{NF} \varkappa \mathrm{B} ＼mathrm{~ 前 立 腺 癌 ~}$

\section{緒言}

癌の浸潤，転移は非常に複雑な過程から成り立って いるが，その過程にさまざまな細胞接着分子が関与し ていることが知られている光2. 細胞間接着を担ってい るのは主にカドへリン分子であり，その結合蛋白質で あるカテニンとももにカドヘリン一カテニン複合体を形 成し，接着機能を果たしている。この複合体の異常に よって癌細胞がバラバラな状態となり，浸潤や転移を 抗こしやすくなる334). また癌細胞が標的藏器において 転移巣を形成するためには癌細胞と血管内皮細胞との 接着が重要なステップとなる．この機序は白血球が炎 症部位へ集積する機構と部分的に類似している可能性 がある．具体的には脈管内を遊走する白血球が血管内 皮細胞上の selectin を介する rolling（緩やかな接着状 態)により充分に減速した後に, ICAM-1 (intercellular adhesion molecule-1) および VCAM-1 (vascular cell adhesion molecule-1) と integrin との間の sticking (強固な接着) が起こることが細静脈を用いた in vivo の実験で示されておう ${ }^{5 / 6)}$ ，この接着には各段階のモデ ルが考えられている7).しかしこの接着機構に関与す る接着分子は癌細胞の種類により少しずつ異なってお り，必ずしも白血球と同様のモデルを考えることには 問題があり，癌種により異なるモデルを考える必要が あると思われる。そこで個々の癌における細胞接着分 子の発現を検討することが血管内皮細胞との接着モデ ルを明らかにし，さらに血行性転移機構の解明につな がると考えられる。一方この $2 \sim 3$ 年の間に，Eselectin, ICAM-1, VCAM-1などの接着分子の遺伝子 発現が転写因子 $\mathrm{NF} \varkappa \mathrm{B}$ (nuclear factor $\varkappa \mathrm{B}$ ) により制

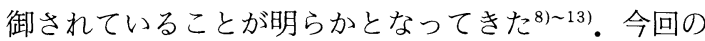
実験では前立腺癌の転移メカニズムの解明を目的とし て， 3 種類の前立腺癌細胞の LNCaP，PC-3，打よび DU145と血管内皮細胞株を用い細胞接着分子の発現 ならびに $\mathrm{NF} \varkappa \mathrm{B}$ にるる発現制御についての検討を 行った。

\section{対象と方法}

（1）細胞株

七ト前立腺癌細胞株 PC-3, DU145とヒ卜悪性黒色腫 細胞株 WM266-4は American Type Culture Collection（ATCC，USA）ょり供与を受け実験に使用した。 ヒ卜肺小細胞性未分化癌細胞 QG90は愛知県がんセン ター，小川博士より供与を受け実験に使用した。ヒト 前立腺癌細胞株 LNCaP は大日本製薬ラボラトリープ ロダクッ（株）より購入し実験に使用した。ヒト血管 内皮細胞株 HUVEC (human umbilical vein endothelial cells）は当大学分子医学研究所分子遺伝部門にお いてヒト臍帯静脈より採取し樹立した細胞株である。 培養液は LNCaP, WM266-4, HUVECには RPMI1640 medium（Gibco BRL）に10\%または15\% fetal bovine serum（FBS） (Gibvo BRL) を加えた ものを，DU145，QG90には MEM medium（Gibco BRL)に10\%FBS を加えたものを使用した．PC-3には DMEM medium（Gibco BRL）に10\%FBS を加えた ものを使用した。

(2) 抗細胞接着分子抗体, 抗 $\mathrm{NF} \varkappa \mathrm{B}$ 抗体およびサイ トカイン

recombinant interleukin $1 \beta$ （IL-1 $\beta$ ） は大塚製薬中 央研究所より供与を受け実験に使用した。E-selectin, ICAM-1, VCAM-1, Sialyl Lewis X, LFA1 (lymphocyte function-associated antigen-1), inte$\operatorname{grin} \alpha 4$ おび $\beta 1$ に対するモノクローナル抗体は CAMFOLIO (USA) より，NF $\varkappa$ B の 65 と 550 に対す るポリクロナール抗体（抗ヒト家鬼抗体）はSANTA CRUZE (USA)より購入した。2 次抗体には FITC 標 識家兔抗マウス IgG またはロダミン標識やぎ抗家鬼 IgG（CAPPEL，USA）を用いた。

（3）免疫蛍光染色

Lab-Tek チェンバースライド (Nunc Co.) 上で細胞 を semi-confluent（約70から80\%スライド上を占める 状態)となるまで培養しアセトンで10分間固定した(一 
$\left.20^{\circ} \mathrm{C}\right)$. phosphate buffer saline $(-)$ (PBS $\left.(-)\right) に$ て 3 回洗浮した後，1次抗体を加え $37^{\circ} \mathrm{C} て ゙ 1$ 時間 incubateした。 $0.05 \%$ トトンX100-PBSにて3 回洗浄 後， 2 次抗体を加え $37^{\circ} \mathrm{C} て ゙ 20$ 分 incubateした。再度 PBS (-)にて 3 [回洗浄しマウントした後, 蛍光顕微 鏡で観察した。1 次抗体，2次抗体とも $3 \%$ bovine serum albumin（BSA）含有 PBSにて $1 ： 100$ に希积 して实験に使用した。

(4) ウェスタンブロット

各紐胞株それぞれ $10^{6}$ cells を RIPA buffer $(20 \mathrm{mM}$ Tris- $\mathrm{HCl}$, SDS $0.1 \%$, Triton X1001\%, sodium deoxycholate $1 \%$ ) に溶解し, $12,000 \mathrm{rpm}, 30$ 分, $4{ }^{\circ} \mathrm{C}$ で遠心した後，上清を採取しタンパク質を調整した。 抽出分画は10\%sodium dodecyl sulfate polya. crylamide gel electro-phoresis (SDS-PAGE) にて泳 動後, gel nitrocellulose 膜（BIO-RAD, USA）に transfer L, 1 次抗体との反応後, WESTERN BLOT KIT (Kirkegaard \& Perry Labo. Inc. Gaithersburg, MD）を用いて染色した。

（5）フローサイトメトリー

各培荃紐胞株 $(10 \mathrm{~cm}$ 径 Dish 1 枚）を0.5 MMEDTA/0.05\%トリプシンで処理した後, PBS $5 \mathrm{ml}$

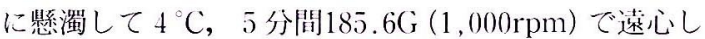
た。細胞をPBSに奬羈し 1 次抗体 $80 \mu 1$ を加え水!で 1 時間反心地さた。.PBSで2 叫洗唃した後，2次抗体 $80 \mu 1$ 在加え氷上で30分間反応させた。さらに細胞を PBS で 2 回洗浄し PBS $1 \mathrm{ml}$ に愳濁後, ナイロンメッ シュ (孔径, $100 \mu \mathrm{m}$ ) 通し Falcon 2050チューブに 懸濁液を移し FACScan（Becton Dickinson 社製）に て細胞表面抗原の解析を行った。

（6）細胞培盖上清中 IL-1，TNF 濃度

各癌紐胞株の継代後 2 HH（培荃液交換前）の培等 上清を採取し，IL-1B，TNF $\alpha$ 測定キット（大场製薬 (株)）を用いた ELISA 法にてIL-1 $\beta$ および TNF $\alpha$ 淽 度を測定した。

（7）単穈細胞接着アッセイ

$10 \mathrm{ng} / \mathrm{ml}$ のIL-1ßでそれぞれ30分，1時間，4時間 刺激した48穴プレートトの semi-confluent の

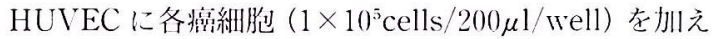
20 分間， $37^{\circ} \mathrm{C}$ で培営した。この時，非特異的接着在防 ぐため120rpm でローテーションした。この後 RPMI 1640 にて 3 [以の洗浮を行い，各洋とも中心部の) 10視野 に扔ける接着した瘦細胞数を直接，顕微鏡にて数え， 平均土標淮愦差を算出した。

Fig. 1 Expression of cell adhesion molecules on prostate cancer cell lines and QG90 by immunofluorescent staining using specific monoclonal antibodies. Expression of E-selectin, ICAM-1 and VCAM-1 were highly elevated before stimulation with IL-1 $\beta$.
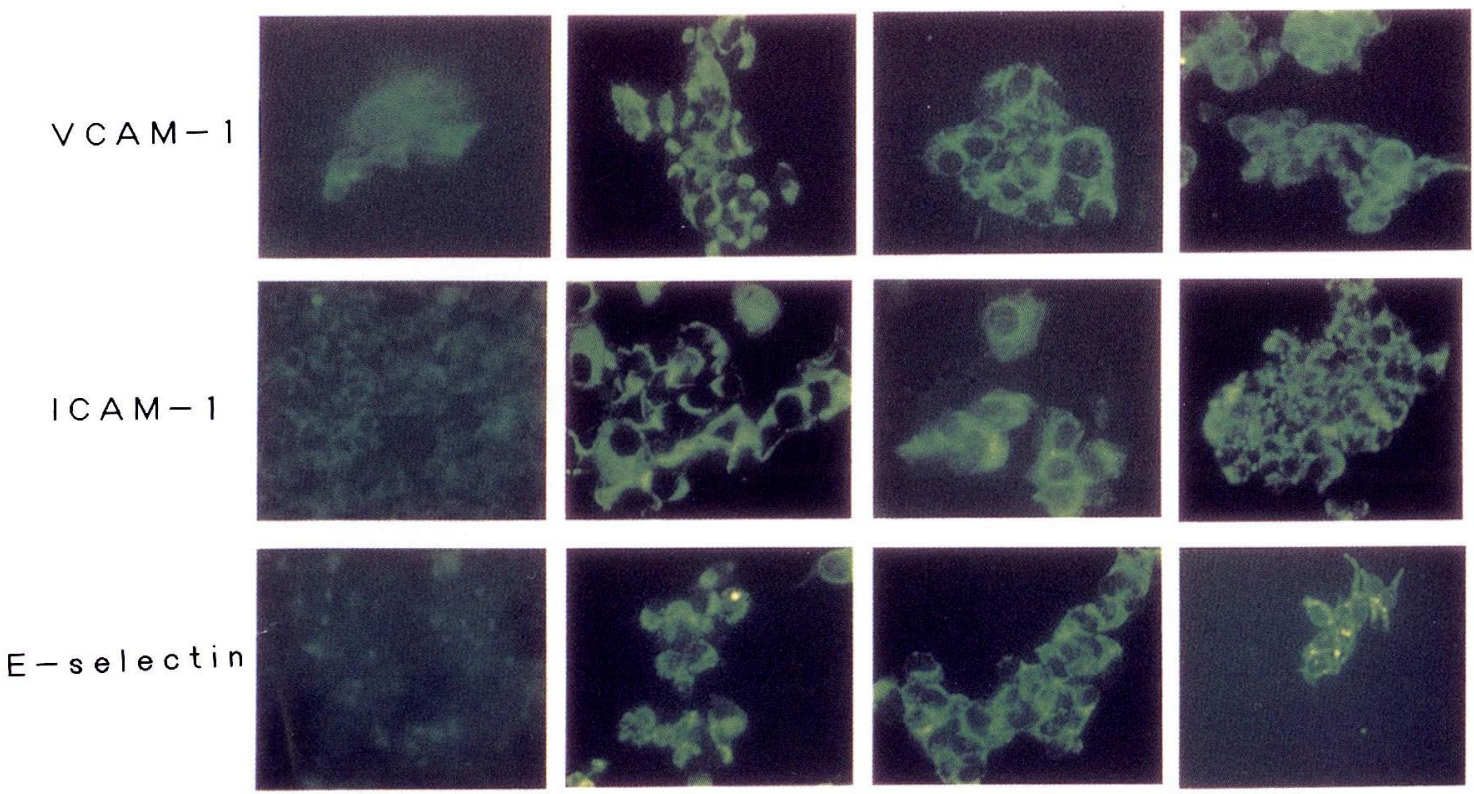

Q G $\quad 90$
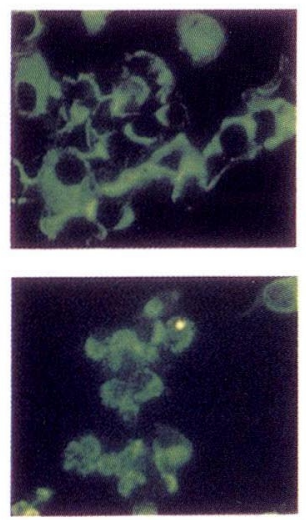

P C 3
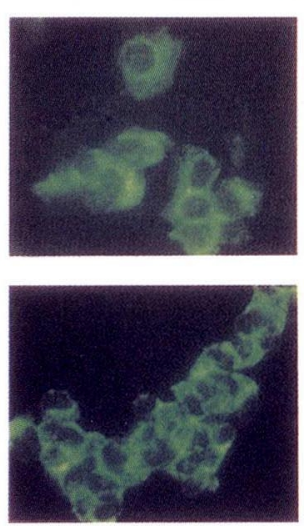

$D \cup 145$
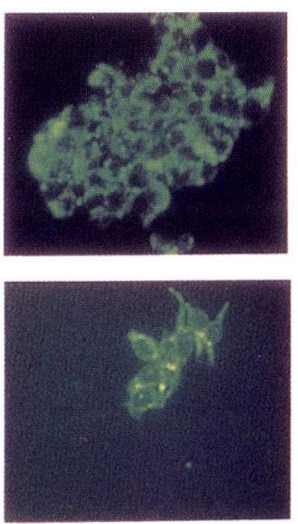

L N C a P 
Fig. 2 Expression of ICAM-1 on prostate cancer cell lines and WM266-4 by FACScan. The cell surface levels of ICAM-1 were high in all cell lines.
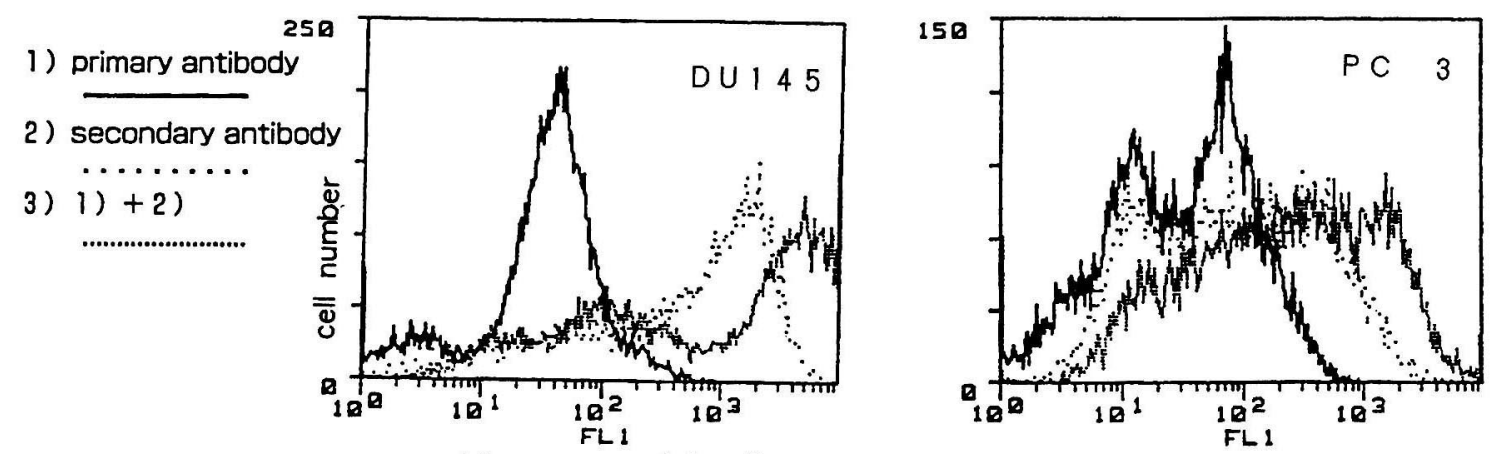

Fluorescence Intensity
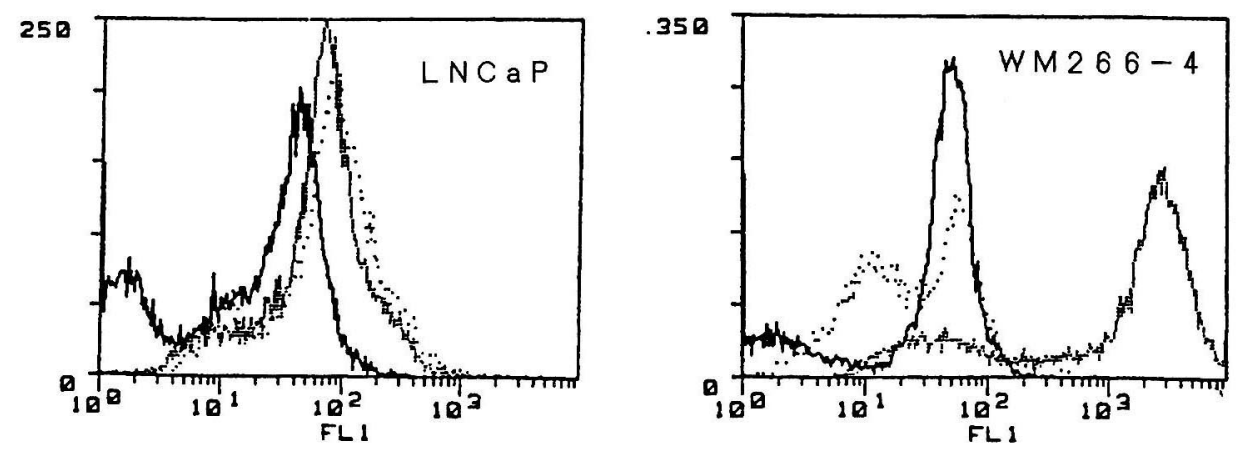

Fig. 3 Expression of $\mathrm{NF} \boldsymbol{x} \mathrm{B}, \mathrm{E}$-selectin, ICAM-1 and VCAM-1 on prostate cancer cell lines by Wester blotting. ICAM-1, VCAM-1 and $\mathrm{NF} \boldsymbol{x} \mathrm{B}$ were strongly expressed on prostate cancer cell lines.

PC-3 DU145 LNCaP

P50

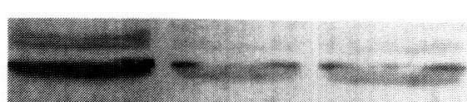

E-selectin

PC-3

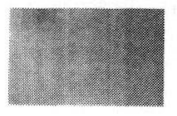

DU145
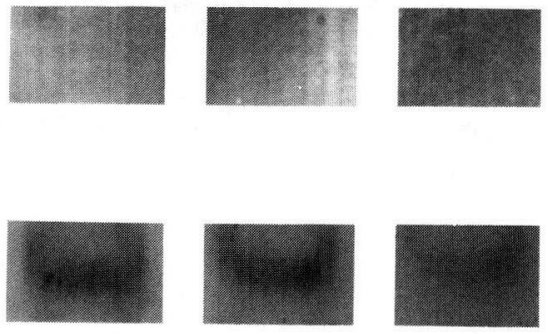

ICAM-1
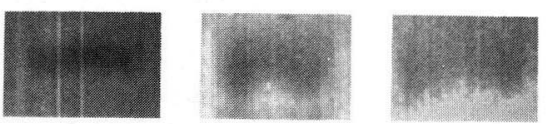

各群の有意差の検定には Welchの $\mathrm{t}$ 検定を用いた。

（8）細胞接着阻害実験

混合培養する30分前に50ng/ml の E-selectin, ICAM-1, VCAM-1に対するモノクローナル抗体を癌 細胞培養上清に加え, 単層細胞接着アッセイを行った.
結 果

（1）細胞接着分子の発現

細胞表面の細胞接着分子の発現は蛍光抗体法, ウエ 
Table 1 Expression of cell adhesion molecules on HUVEC and cancer cell lines

\begin{tabular}{|c|c|c|c|c|c|c|c|c|c|c|c|c|}
\hline & \multicolumn{2}{|c|}{ HUVEC } & \multicolumn{2}{|c|}{ QG90 } & \multicolumn{2}{|c|}{ WM266-4 } & \multicolumn{2}{|c|}{$\mathrm{PC}-3$} & \multicolumn{2}{|c|}{ DU145 } & \multicolumn{2}{|c|}{ LNCaP } \\
\hline & Control & $\begin{array}{l}\text { after } \\
\text { IL-1 } \\
\text { stimu- } \\
\text { lation }\end{array}$ & Control & $\begin{array}{l}\text { after } \\
\text { IL-1 } \beta \\
\text { stimu- } \\
\text { lation }\end{array}$ & Control & $\begin{array}{l}\text { after } \\
\text { IL-1 } \beta \\
\text { stimu- } \\
\text { lation }\end{array}$ & Control & $\begin{array}{l}\text { after } \\
\text { IL-1 } \beta \\
\text { stimu- } \\
\text { lation }\end{array}$ & Control & $\begin{array}{l}\text { after } \\
\text { IL-1 } \beta \\
\text { stimu- } \\
\text { lation }\end{array}$ & Control & $\begin{array}{l}\text { after } \\
\text { IL-1 } \\
\text { stimu- } \\
\text { lation }\end{array}$ \\
\hline E-selectin & - & $H$ & - & + & \pm & + & + & + & + & + & \pm & \pm \\
\hline ICAM-1 & \pm & + & - & - & + & + & H & H & H & $H$ & \pm & \pm \\
\hline VCAM-1 & \pm & + & - & - & \pm & \pm & + & + & + & + & \pm & \pm \\
\hline Sialyl-Lewisx & \pm & \pm & \pm & + & + & + & \pm & \pm & + & + & \pm & \pm \\
\hline LFA-1 & - & - & - & \pm & \pm & \pm & \pm & \pm & + & + & - & - \\
\hline Integrin $\alpha 4$ & - & - & - & \pm & \pm & \pm & \pm & \pm & \pm & \pm & + & + \\
\hline Integrin $\beta 1$ & \pm & \pm & \pm & + & \pm & \pm & + & + & + & + & + & + \\
\hline
\end{tabular}

+ : strongly stained + :stained \pm : eqivocal - : not stained

Fig. 4 Induction of cancer cells-HUVEC adhesion by IL-1 $\beta$. HUVEC were treated with $10 \mathrm{ng} / \mathrm{ml} \mathrm{IL}$ $1 \beta 30 \mathrm{~min}-4 \mathrm{~h}$. Prostate cancer cells were added and incubated for $20 \mathrm{~min}$ at $37^{\circ} \mathrm{C}$ with rotation (120rpm). The number of cancer cells adhered to HUVEC monolayer was counted. Standerd error bars were obtained from the results of three independent experiments.
QG90-HUVEC

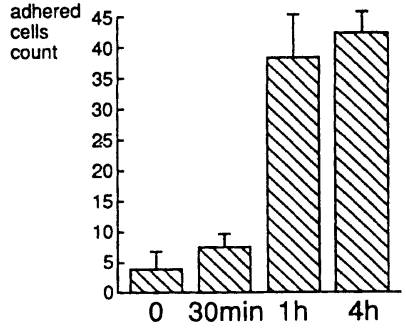

DU145-HUVEC

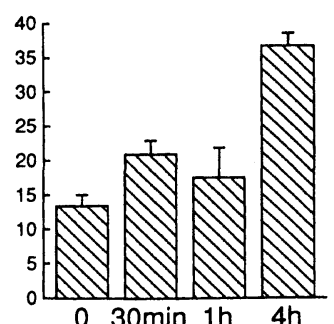

PC 3-HUVEC

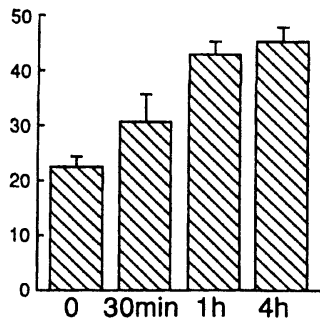

LNCaP-HUVEC

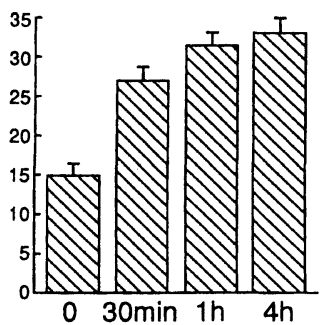

スタンブロット, FACScan により確認した. HUVEC 上では TNF $\alpha$ あるいは IL-1 $\beta$ の刺激により $\mathrm{E}$ selectin が 4 時間, ICAM-1が 8 時間, VCAM-1が12か ら24時間をピークに発現が誘導された。一方, PC-3, DU145においては TNF $\alpha$ あるいは IL- $1 \beta$ 未刺激の状 態でICAM-1の発現が強くE-selectin, VCAM-1も若
Table 2 Concentration of IL- $1 \beta$ and TNF $\alpha$ in culture medium

\begin{tabular}{l|c|c}
\hline & $\mathrm{IL}-1 \beta(\mathrm{pg} / \mathrm{ml})$ & $\mathrm{TNF} \alpha(\mathrm{pg} / \mathrm{ml})$ \\
\hline QG90 & 0.52 & $<0.5$ \\
WM266-4 & 1.44 & $<0.5$ \\
DU145 & $<0.25$ & $<0.5$ \\
LNCaP & $<0.25$ & $<0.5$ \\
PC3 & 4.27 & $<0.5$ \\
\hline
\end{tabular}

干の発現を認めた. しかし LNCaPではこれら細胞接 着分子の発現は弱く TNF $\alpha$ あるいは IL- $1 \beta$ 刺激を加 えてもその発現は誘導されなかった.コントロールと した他の癌細胞株 QC90, WM266-4では WM266-4で ICAM-1の発現が強く認められた以外は E-selectin, VCAM-1の発現は見られなかった (Fig. 1，2，3)。さ らに E-selectin, ICAM-1, VCAM-1のリガンドについ てはDU145が E-selectinのリガンドである sialyl Lewis X と ICAM-1のリガンド LFA-1を発現してお り, PC-3, DU145，LNCaPすべての前立腺癌細胞株 が integrin $\beta 1$ を発現していた（Table 1 ).

尚, FACScan では0.5mM EDTA/0.05\%トリプシ ン処理により E-selectin, VCAM-1の抗原性が失われ た可能性があり E-selectin，VCAM-1は認められな かった。

（2）血管内皮細胞に対する接着能

HUVECへの接着能について細胞株別に比較する と, IL-1 $\beta$ 未刺激の状態では QC90に比べ 3 種の前立腺 癌細胞株の接着細胞数は有意に多かった $(\mathrm{p}<0.05)$. しかし IL- $1 \beta$ 刺激後 30 分， 1 時間と経過し接着細胞数 が時間依存的に増加するにしたがい QG90 との差がな くなり 4 時間でほほプラトーに達した（Fig. 4)。 
（3）培養上清中 $\mathrm{TNF} \alpha$, IL- $1 \beta$ 濃度

$\mathrm{TNF} \alpha, \mathrm{IL}-1 \beta$ とも低值あるいは検出感度以下で あったが PC-3のみ $4.27 \mathrm{pg} / \mathrm{ml}$ と高い值を示した (Table 2).

(4) 抗接着分子抗体による接着阻害効果

各癌細胞株と HUVEC の接着における細胞接着分 子の重要性を検討する目的で抗接着分子抗体による接 着阻害実験を行った。QC90は抗 E-selectin 抗体で, PC-3, DU145は抗 ICAM-1抗体にて有意な接着阻害効 果が認められた（ $<<0.05$ (Fig. 5).

（5）転写因子 $\mathrm{NF} \varkappa \mathrm{B}$ の発現と活性化

$\mathrm{NF} \varkappa \mathrm{B}$ （p65，p50）に対するポリクローナル抗体を 用いたウェスタンブロットでは実験に用いたすべての 細胞株で発現が確認された (Fig. 3). また蛍光染色で は p 65 サブュニットは IL- $1 \beta$ 未刺激の状態で細胞質に 存在し (不活性状態) IL- $1 \beta$ 刺激後30分後には核への移 動(活性化状態)が認められた。p50サブユニットは IL-
$1 \beta$ 刺激前よりも核にも存在し IL- $1 \beta$ 刺激により核で の染色が若干増強した（Fig. 6).

\section{考 察}

細胞接着分子は癌の浸潤，転移において重要な役割 を果たしている.今回，この中で特に血管内皮細胞と の接着機構に関与すると考えられる細胞接着分子の発 現様式を前立腺癌細胞株を用いて検討した。さらにこ れらの接着分子の発現を promote すると考えられる 転写因子 $\mathrm{NF} \varkappa \mathrm{B}$ に着目しその活性化についても検討 を加えた，今回の研究で判ったことを要約すると以下 のようになる。

1. 前立腺癌細胞株では血行性転移より得られた PC-3とDU145はよく似た培養分子の発現パターンを 示したが，リンパ節転移より得られた $\mathrm{LNCaP}$ は異な る発現パターンを示した.2. 血管内皮細胞への接着能 はサイトカイン未刺激では前立腺癌細胞株が他の癌細 胞株より有意に高く，サイトカイン刺激後はサイトカ

Fig. 5 Contribution of three cell adhesion molecules, E-selectin, ICAM-1 and VCAM-1, to the adhesion of cultured prostate cancer cells to IL-1 $\beta$-activated HUVEC. All prostate cancer cells exhibited a significant inhibition of adhesion by treatment with the anti-ICAM-1 antibodies. Bars, SD.

QG90

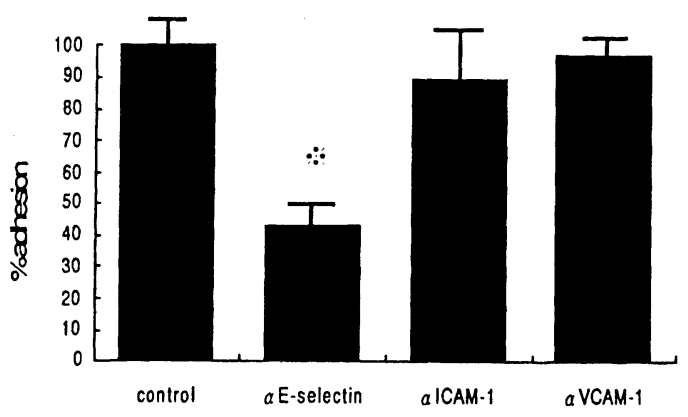

PC-3

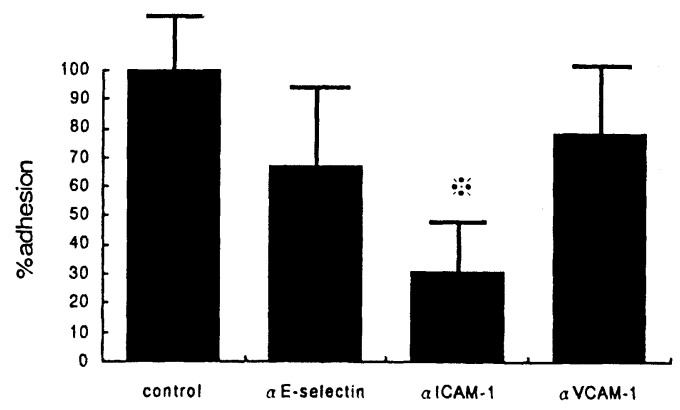

DU145

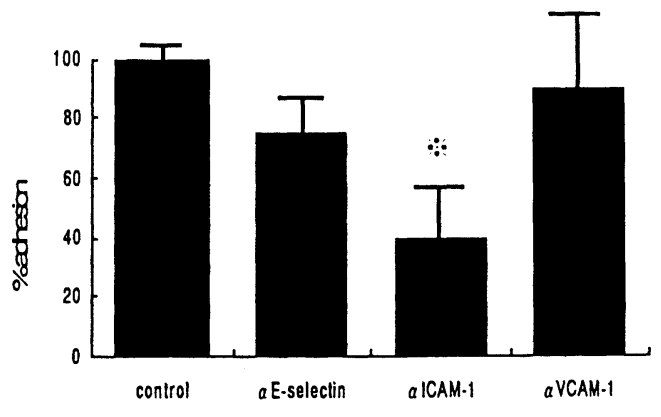

LNCaP

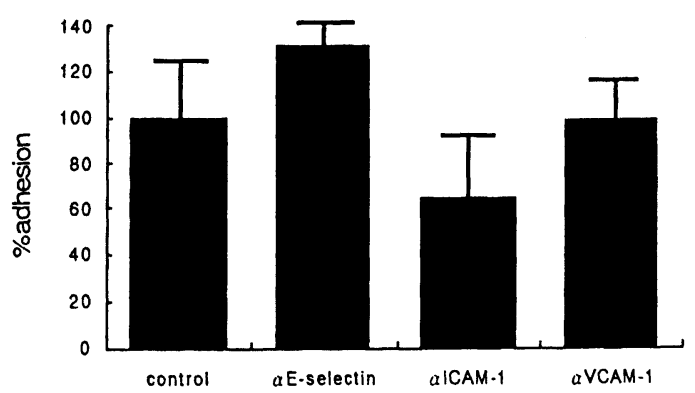


Fig. 6 Nuclear translocation of $\mathrm{NF} \kappa \mathrm{B} . \mathrm{IL}-1 \beta(10 \mathrm{ng} / \mathrm{ml})$ was added for the indicated period before PC-3 cells were fixed for immuno-staining.
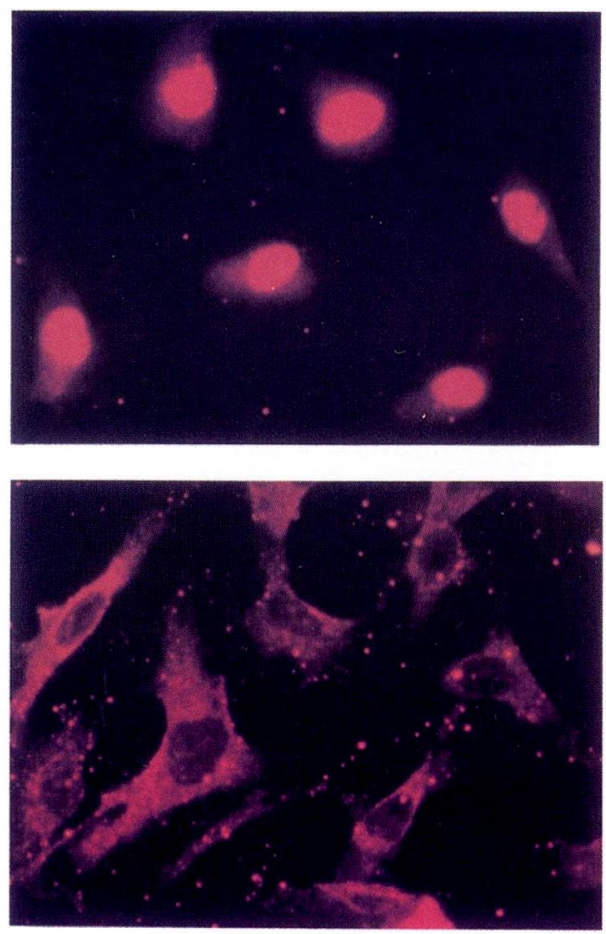

$\operatorname{IL}-1 \beta(-)$
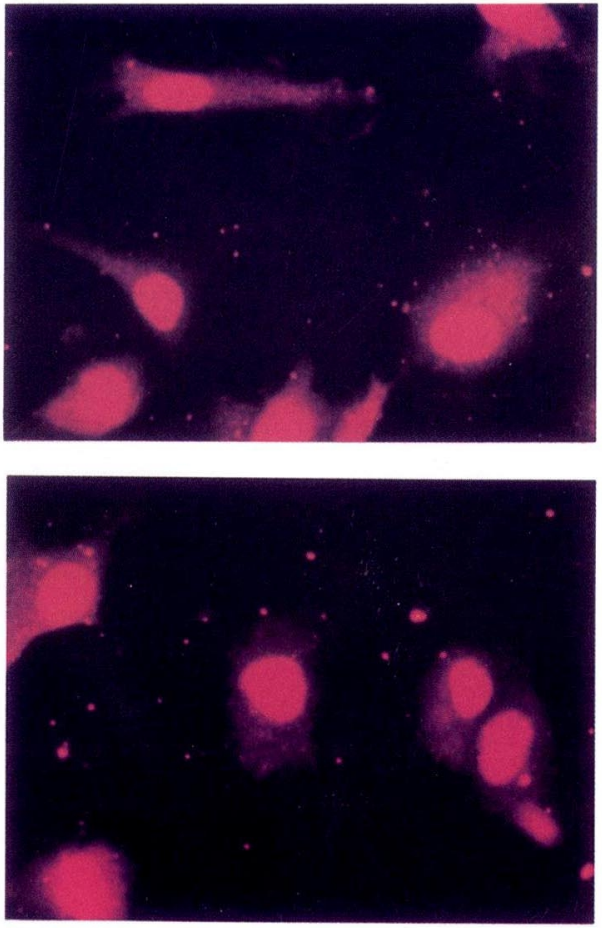

after $30 \mathrm{~min}$ adding IL-1 $\beta$ 10ng/ml
イン刺激後は差がなくなった.3. 前立腺癌細胞株と血 管内皮細胞の接着において中心的な役割をはたしてい るのはICAM-1であると考えられた。4. 前立腺癌細胞 株 3 種は NF $\boldsymbol{N}$ B を発現しておりサイトカインによる 活性化 (細胞質から核への)移動)も正常に認められた。

前立腺癌は発見時すでに遠隔転移していることもし ばしばで，ホルモン療法に反応しなくなった再燃癌は 特に治療に難渋する．著者は前立腺癌の転移機構を解 明することが早期の転移阻止につながると考え，高転 移能を有する前立腺癌細胞株, 即ちリンパ節転移由来 0 LNCaP, 骨転移由来の PC-3, 脳転移由来の DU145 について血管内皮との接着への関与が推察されている 細胞接着分子の発現についての検討を行った ${ }^{14115)}$. ま たコントロールの癌紐胞株としてはすでに血管内皮紐 胞との E-selectin 依存性の接着機構が明らかになりつ つある肺小細胞性未分化癌細胞株 QG90 ${ }^{16) 17)}$, ICAM-1 を強く発現している悪性黒色腫細胞株 WM266-4 ${ }^{18)}$ 用いた。前立腺癌細胞株にお打る細胞接着分子の発現
パターンをみると特に ICAM-10発現が強かったが血 行性転移株（PC-3，DU145）とリンパ行性転移株 (LNCaP) で発現強度，パターンの相違がみられたこ とは転移モデルを考えるうえで大変興味深い。

さらにこの前立腺癌細胞株 3 株の高い高転移能とＩ血 管内皮細胞との接着能との間に相関があるか検討して みたところ，サイトカイン未刺激では QC90より明ら かに HUVEC への接着能は高かった.これは恒常的に 発現している E-selectin, ICAM-1, VCAM-1によると 考えられる。しかしサイトカイン刺激後はQC90上に も E-selectin が, HUVEC 上に E-selectin, ICAM-1, VCAM-1が誘導されてくるため接着細胞数で徐々に 差がなくなってくることが推察された。

E-selectin が培㽰癌細胞の血管内皮細胞への接着に 重要な役割を果たしていることは Sialyl Lewis X 発 現変異大腸癌細胞株を用いて行われた Matsushita ら ${ }^{19)}$ の接着実験によって明らかにされている。しかし この実験では E-selectin は血管内皮細胞上に発現して 
おり癌細胞上はリガンドである Sialyl Lewis X が発 現していた。今回の実験結果では前立腺癌細胞上にも E-selectin が存在することが示された. E-selectinが rollingに関与するのに対し sticking において重要な 役割を果たすことが推測されているのが ICAM-1であ る. ICAM-1については消化器系の癌, メラノーマなど での発現がすでに報告されており血行性転移への関与 が推察されている ${ }^{20)}$. 今回の実験で前立腺癌において も ICAM-1が強く発現しており,さらに抗体による接 着阻害効果ももっとも高かったことより, ICAM-1が 血行性転移において重要な意義をもつことが証明され た.

また E-selectin, ICAM-1, VCAM-1は IL-1, TNF などのサイトカイン刺激により誘導されることから各 細胞上清中の IL-1 $\beta, T N F \alpha$ 濃度を ELISA 法にて測 定したが PC-3で IL-1 $\beta$ 濃度が若干高かった以外はす べて低值であった。この結果のみで autocrine 機構に よる細胞へのサイトカインによる恒常的刺激を否定す ることはできないが細胞接着分子の発現誘導には最低 $0.1 \sim 1 \mathrm{ng} / \mathrm{ml}$ の IL- $1 \beta, \mathrm{TNF} \alpha$ 濃度は必要と考えられ ることよりその可能性は低いと考えられた。

さらにこれらの細胞接着分子の発現誘導を転写因子 のレベルで考えてみた。転写因子 $\mathrm{NK} \varkappa \mathrm{B}$ は $\varkappa \mathrm{B}$ 配列 (GGGRNNYYCC) と呼ばれるDNA に結合し，その 制御下の遺伝子の発現を誘導する。 $\varkappa \mathrm{B}$ 配列を持つ遺 伝子には, IL-2受容体の $\alpha$ 鎖や $\beta$ インターフェロン等 に代表される免疫系の受容体やサイトカインが多いこ とから ${ }^{21)}, \mathrm{NF} \varkappa \mathrm{B}$ は生理的に重要な因子として注目さ

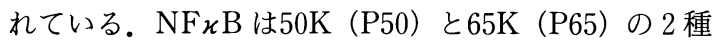
類の蛋白質からなるへテロ二量体であり休止期の細胞 では細胞質に存在し， I $x$ B との複合体として存在す る. サイトカインなどの細胞外からのシグナルに反応 し $\mathrm{I} \varkappa \mathrm{B}$ がリン酸化される $\mathrm{NF} \varkappa \mathrm{B}$ から離れることによ り $\mathrm{NF} \varkappa \mathrm{B}$ は活性化された核内に移行し転写活性をあ らわす ${ }^{22}$ (Fig. 7). E-selectin, ICAM-1, VCAM-1遺 伝子はいずれもプロモーター領域に $\varkappa \mathrm{B}$ 配列を持ち $\mathrm{NF} \varkappa \mathrm{B}$ ににより発現制御がなされていると考えられ ている ${ }^{8) \sim 13)}$. 今回, 前立腺癌細胞株において Eselectin, ICAM-1, VCAM-1の発現が認められたこと から NF B が活性化された状態にあることを予測し たが実際には $\mathrm{NF} \varkappa \mathrm{B}$ は細胞質に存在し不活性型で存 在していた. $\mathrm{NF} \varkappa \mathrm{B}$ はさまざまの生理活性物質の遺伝 子発現を制御しており特に血管内皮細胞において IL$1 \beta, \mathrm{TNF} \alpha$ で活性化され細胞接着分子の発現を誘導
Fig. 7 Activation of $\mathrm{NF}_{\mathcal{K}} \mathrm{B}$. Upon stimulation by signals such as cytokines $\mathrm{I} \kappa \mathrm{B}$ is separated from $\mathrm{NF} \varkappa \mathrm{B}$ and $\mathrm{NF} \mathcal{H} \mathrm{B}$ then moves into nucleus where it activates target genes.

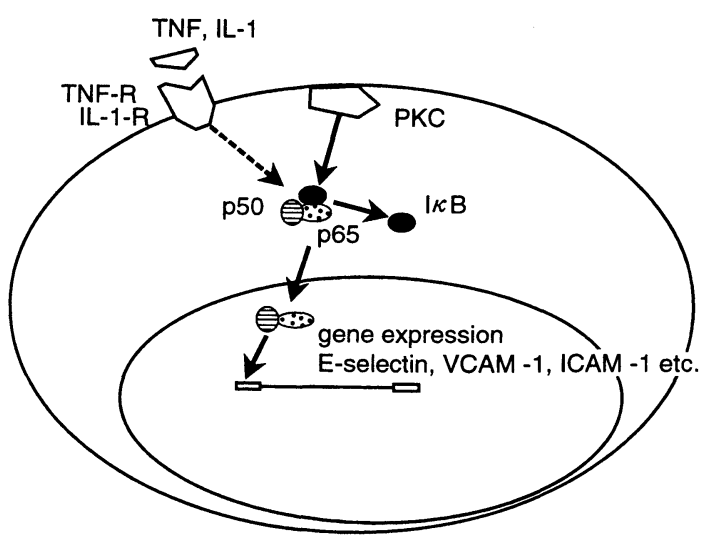

することがよく知られている. 今回, IL- $1 \beta, T N F \alpha$ 刺 激により $\mathrm{NF} \varkappa \mathrm{B}$ が活性化されるにもかかわらず，Eselectin, ICAM-1, VCAN-1の発現レベルに変化がみ られなかったことより, 前立腺癌細胞では核内におい て $\mathrm{NF} \varkappa \mathrm{B}$ が $\varkappa \mathrm{B}$ 配列に結合できないなんらかの機序 (inhibitor, mutation など) が存在する可能性が推察さ れる.さらに, 前立腺癌細胞株においては E-selectin, ICAM-1, VCAM-1の発現誘導は NF $\varkappa$ B のみによるも のではなく他の転写因子の関与が強く示唆されたので ある。

近年, 癌の浸潤, 転移を様々なサイトカイン, 細胞 接着分子の遺伝子発現に関与している転写因子レベル でアンチセンス等を用いて抑制しようとする試みがな され，すでに動物実験ではその効果が報告されてい る ${ }^{23) ~ 25)}$. したがって癌細胞上に発現し転移に関与して いる接着分子とその遺伝子発現を調節している転写因 子を解明することは癌の治療に新しい局面を展開する こととなる. 今回, 細胞接着分子の遺伝子発現ならび に発現誘導に関わる転写因子 $\mathrm{NF} \varkappa \mathrm{B}$ について前立腺 癌細胞株における特徴を捉えることができた。これら の知見は近い将来の前立腺癌の遺伝子治療に役立つも のと確信する。

\section{結 語}

1) 3 種類の前立腺癌細胞株（PC-3, DU145, $\mathrm{LNCaP})$ を用いて前立腺癌の血行性転移に関与すると 思われる細胞接着分子の発現様式を検討した。

2) 前立腺癌細胞株では E-selectin, ICAM-1, VCAM-1が発現しており特にICAM-1の発現が強 
かった.また血管内皮細胞との接着においても ICAM1が主要な役割を演じていることが推察された.

3） E-selectin, ICAM-1，VCAM-1はいずれもプロ モーター領域に $\varkappa \mathrm{B}$ 配列を持ちその遺伝子の発現誘導 は転写因子 $\mathrm{NF} \varkappa \mathrm{B}$ の制御をうけていると考元られて いるが前立腺癌細胞株では他の転写因子の関与も考え られた。

稿を終えるにあたり，御指導ならびに御校閲を賜った恩 師郡健二郎教授, 本学医学研究所分子遺伝部門岡本 尚教 授に深く感謝します.なお, 本論文の要旨は第83回日本泌尿 器科学会総会にて発表した。

\section{文献}

1) Albelda, S.M.: Biology of disease: Role of integrins and other cell adhesion molecules in tumor progression and metastasis. Lab. Invest., 68, 4-17, 1993.

2) Fidler, I.J.: Selection of successive tumor lines for metastasis. Nature (New Biol.), 242, 148-149, 1973.

3) Takeichi, M.: Cadherin cell adhesion receptors as a morphogenetic regulator. Science, 251, 1451-1455, 1991.

4) Siozaki, H., Tahara, H., Oka, H., Miyata, M., Kobayashi, K., Tamura, S., Iihara, K., Doki, Y., Hirano, S., Takeichi, M. and Mori, T.: Expression of immunoreactive E-cadherin adhesion molecules in human cancers. Am. J. Pathol., 139, 17-23, 1991.

5) Ley, K., Gaehtgens, P., Fennie, C., Singer, M.S., Lasky, L.A. and Rosen, S.D.: Lectin-like cell adhesion molecule 1 med iates leukocyte rolling in mesenteric venules in vivo. Blood, 77, 25532555, 1991.

6) Von Andorian, U.H., Chmbers, J.D., McEvoy, L. M., Bargatze, R.F., Arfors, K.E. and Butcher, E. C.: Two-step model of leukocyte-endothelial cell interaction in inflammation: Distinct roles for LECAM- 1 and the leukocyte $\beta 2$ integrins in vivo. Proc. Natl. Acad. Sci. U.S.A., 88, 75387542, 1991.

7) Butcher, E.C.: Leukocyte-endothelial cell recognition: Three (or more) steps to specificity and diversity. Cell, 67, 1033-1036, 1991.

8) Schindler, U. and Baichwal, V.R.: Three NF $x$ $\mathrm{B}$ binding sites in the human E-selection gene required for maximal tumor nectosis factor alpha-induced expression. Mol. Cell. Biol., 14, 5820-5831, 1994.

9) Neish, A.S., Williams, A.J., Palmer, H.J., Whitley, M.Z. and Collins, T.: Functional analysis of the human vascular cell adhesion molecule 1 promoter. J. Exp. Med., 176, 1583-1593, 1992.

10) Voraberger, G., Schafer, R. and Stratowa, C.: Cloning of human gene for intercellular adhesion molecule 1 and its $5^{\prime}$-regulatory region. J. Immunol., 147, 2777-2786, 1991.

11) Montgomery, K.F., Osborn, L., Hession, C., Tizard, R., Goff, D., Vassallo, C., Tarr, P.I., Bomsztyk, K., Lobb, R., Harlan, J.M. and Pohlman, T.H.: Activation of endothelialleukocyte adhesion molecule 1 (ELAM-1) gene transcription. Proc. Natl. Acad. Sci. U.S.A., 88, 6523-6527, 1991.

12) Whelan, J., Ghersa, P., Huijsduijnen, R.H., Gray, J., Chandra, G., Talabot, F. and DeLamarter, J.F.: An NF $\boldsymbol{x}$ B-like factor is essential but not sufficient for cytokine induction of endothelialleukocyte adhesion molecule 1 (ELAM-1) gene transcription. Nuc. Acids Res., 19, 2645-2653, 1991.

13) Ledebur, H.C. and Parks, T.P.: Transcriptional regulation of intercellular adhesion molecule-1 gene by inflammatory cytokines in human endothelial cells. J. Biol. Chem., 270, 933-943, 1995.

14) Olea, N., Sakabe, K., Soto, A.M. and Sonnenshein, C.: The proliferative effect of "antiandrogens" on the androgensensitive human prostate tumor cell line LNCaP. Endocrinology, 126, 1457-1463, 1990.

15) Carruba, G., Pavone, C., Macaluso, P., Mesiti, M., d'Aquino, A., Vita, G., Sica, G. and Castignetta, L.: Morphometory of in vitro systems: An image analysis of two human prostate cancer cell lines (PC 3 and DU145). Path. Res. Pract., 185, 704-708, 1989.

16) Kinjo, M., Oka, K., Naito, S., Kohga, S., Tanaka, K., Oboshi, S., Hayata, Y. and Yasumoto, K.: Thromboplastic and fibrinolytic activities of cultured human cancer cell lines. J. Biol. Chem., 268, 26790-26795, 1993.

17) Tozawa, K., Sakurada, S., Kohri, K. and Okamoto, T.: Effects of anti-NF $\mathcal{x}$ B reagents in blocking adhesion of human cancer cells to vascular endothelial cells. Cancer Res., 55, 4162 -4167, 1995.

18) Martin-Padura, I., Mortarini, R., Lauri, D., Bernasconi, S., Sanchez-Madrid, F., Pariani, G., Mantovani, A., Anichini, A. and Dejana, E.: Heterogeneity in human melanoma cell adhesion to cytokine activated endothelial cells correlates with VLA-4 expression. Cancer Res., 
51, 2239-2241, 1991.

19) Matsushita, Y., Nakamori, S., Seftor, E.A., Hendrix, M.J.C. and Irimura, T.: Human colon carcinoma cells with increased invasive capacity obtained by selection for sialyldimeric Lex antigen. Exp. Cell Res., 196, 2025, 1991.

20) Johnson, J.P., Stade, B.G., Holzmann, B., Schwable, W. and Riethmuller, G.: De novo expression of intercellular-adhesion molecule 1 in melanoma correlates with increased risk of metastasis. Proc. Natl. Acad. Sci. U.S.A., 86, 641-644, 1989.

21) Kawakami, K., Scheidereit, C. and Roeder, R. : Identification and purification of a human immunoglobulin enhancer-binding protein $(\mathrm{NF} \varkappa$ B) that activates transcription from human immunodeficiency virus type 1 promoter in vitro. Proc. Natl. Acad. Sci. U.S.A., 85, 47004704, 1988.

22) Baeuerle, P.A: The inducible transcription activator $\mathrm{NF} \varkappa \mathrm{B}$ : Regulation by distinct protein subunits. Biochem. Biophs. Acta, 1072, 63 $-80,1991$.

23) Higgins, K.A., Perez, J.R., Coleman, T.A., Dorshkind, K., McComas, W.A., Sarmiento, U.M., Rosen, C.A. and Narayanan, R., Antisense inhibition of $\mathrm{p} 65$ subunit of $\mathrm{NF} \varkappa \mathrm{B}$ blocks tumorigenecity and causes tumor regression. Proc. Natl. Acad. Sci. U.S.A., 90, 9901-9905, 1993.

24) Kitajima, I., Shinohara, T., Bilakovics, J., Brown, D.A., Xu, X. and Nerender, M. : Ablation of transplanted HTLV-1 Taxtransformed tumors in mice by antisense inhibition of $\mathrm{NF} \varkappa$ B. Science, 258, 1792-1795, 1992.

25) Sokoloski, J.A., Sartorelli, A.C., Rosen, C.A. and Narayanan, R.: Antisense oligonucleotides to the p65 subunit of $\mathrm{NF} \varkappa$ B block $\mathrm{CD} 11 \mathrm{~b}$ expression and alter adhesion properties of differentiated HL-60 granulocytes. Blood, 82, 625-632, 1993.

（1996年1月8日受付，6月19日受理，特別掲載） 